\title{
PENGARUH UMKM TERHADAP PENDAPATAN NASIONAL BERDASARKAN KELOMPOK USAHA TAHUN 2014-2018
}

\section{THE INFLUENCE OF MSME ON NATIONAL INCOME BASED ON BUSINESS GROUP 2014-2018}

\author{
Euis Sartika ${ }^{1 *}$, Anny Suryani' ${ }^{2}$ \\ 1) Jurusan Administrasi Niaga Politeknik Negeri Bandung,, Jl. Gegerkalong Hilir Ds. Ciwaruga Bandung \\ *euissartika_sartika@yahoo.com \\ 2) Jurusan Akuntansi Politeknik Negeri Bandung, J1. Gegerkalong Hilir Ds. Ciwaruga Bandung
}

\begin{abstract}
MSMEs (Micro, Small, and Medium Enterprises) have a strategic role in national income. The facts show that MSMEs are proven to be able to survive during the monetary and economic crisis. MSMEs also play a major role in absorbing labor and being able to distribute development results. This study aims to analyze the factors that influence the development of MSMEs on national income. The data used are quantitative secondary data in the form of time series (years) and cross section data (business groups) and the method used is panel data regression. Panel data regression is a combination of Cross Section data and Time Series data, where the same Cross Section unit is measured at different times. The response variable is National Income (GRDP) and the predictor variables are Number of Workers (TKERJA), Number of MSMEs (JUSAHA), INVESTMENT, and EXPORT. Data obtained from BPS, Kemenkop and UMKM, as well as BI. The results showed that the best model is the Fixed Effect model, the variables that have a significant effect on national income (GRDP) are INVESTMENT and EXPORT. Based on the RSquared value, the $R 2$ result is $80.34 \%$, meaning that $80.34 \%$ of the National Income (GDP) is influenced by the variables JUSAHA, INVESTMENT, EXPORT, and WORKERS, the remaining $19.66 \%$ is influenced by other factors.
\end{abstract}

Keywords: MSMEs, panel data regression, business groups.

\begin{abstract}
ABSTRAK
UMKM (Usaha Mikro, Kecil, dan Menengah) memiliki peran strategis dalam pendapatan nasional. Fakta menunjukkan bahwa UMKM terbukti mampu bertahan saat terjadi krisis moneter dan ekonomi. UMKM juga berperan besar dalam menyerap tenaga kerja dan mampu mendistribusikan hasil pembangunan. Penelitian ini bertujuan untuk menganalisis faktor-faktor yang mempengaruhi perkembangan UMKM terhadap pendapatan nasional. Data yang digunakan adalah data sekunder kuantitatif berupa time series (tahun) dan data cross section (kelompok usaha) dan metode yang digunakan adalah regresi data Panel. Regresi data panel merupakan kombinasi dari data Cross Section dan data Time Series, dimana unit Cross Section yang sama diukur pada waktu yang berbeda. Variabel responnya adalah Pendapatan Nasional (PDRB) dan variabel prediktornya adalah Jumlah Tenaga Kerja (TKERJA), Jumlah UMKM (JUSAHA), INVESTASI, dan EKSPOR. Data diperoleh dari BPS, Kemenkop dan UMKM, serta BI. Hasil penelitian menunjukkan
\end{abstract}


bahwa model terbaik adalah model Fixed Effect, variabel yang berpengaruh signifikan terhadap pendapatan nasional (PDRB) adalah INVESTASI dan EKSPOR. Berdasarkan nilai R-Squared, diperoleh hasil $\mathrm{R}^{2}$ adalah $80,34 \%$, artinya $80,34 \%$ Pendapatan Nasional (PDB) dipengaruhi oleh variabel JUSAHA, INVESTASI, EKSPOR, dan PEKERJA, sisanya $19,66 \%$ dipengaruhi oleh faktor lain.

\section{Kata kunci: UMKM, Regresi data panel, kelompok usaha}

\section{PENDAHULUAN}

UMKM memiliki peranan penting dalam perekonomian nasional. Fakta ini dibuktikan saat krisis ekonomi tahun 1998, banyak usaha berskala besar mengalami kebangkrutan, akan tetapi UMKM terbukti tangguh dan memiliki daya tahan yang kuat dalam krisis tersebut (Kemenkeu, Ini Bentuk Perhatian Pemerintah terhadap UMKM, 2018). UMKM juga memiliki peran yang besar terhadap daya serap tenaga kerja serta dalam mendistribusikan hasil-hasil pembangunan. Peran UMKM dalam kehidupan masyarakat kecil yakni : a) mengentaskan kemiskinan , b) memperkecil jurang ekonomi antara yang miskin dengan kaya, dan c) memberikan pemasukan devisa. Dukungan Pemerintah terhadap UMKM antara lain : penurunan tarif PPh Final menjadi 0,5 persen, mempercepat perijinan dengan meluncurkan single submission, mendorong kemudahan dalam permodalan dengan menurunkan bunga pinjaman (Kemenkeu, Ini Bentuk Perhatian Pemerintah terhadap UMKM, 2018). Berdasarkan data BPS, kontribusi UMKM terhadap PDB mencapai 61,41\% dengan jumlah UMKM hampir mencapai 60 juta unit. Kemkominfo menyatakan tahun 2018 sebanyak 9,61 juta unit UMKM sudah memanfaatkan platform online (Kemkominfo, 2018). Keuntungan penggunaan teknologi digital bagi UKM Indonesia adalah : kenaikan pendapatan sebesar 80\%, peningkatan lapangan kerja sebesar1,5 kali, meningkatkan inovatif sebesar 17 kali lebih, dan lebih kompetitif di pasar internasional. Namun berdasarkan data di lapangan, beberapa permasalahan yang dihadapi oleh UMKM di era globalisasi antara lain : kurangnya permodalan, kurangnya kemampuan manajerial dan keterampilan mengorganisir, terbatasnya pemasaran, persaingan yang kurang sehat dan desakan ekonomi yang mengakibatkan ruang lingkup usaha menjadi sempit dan terbatas (Rahmini, 2017).

Struktur usaha di Indonesia tahun 2018 berdasarkan kelompok usaha UMKM dapat ditunjukkan sebagai berikut : 
Tabel 1.1 Kontribusi UMKM dalam Angka

\begin{tabular}{ll}
\hline Kontribusi terhadap Bidang & Besar Kontribusi \\
\hline Total Tenaga Kerja & $97 \%$ \\
Total Lapangan Kerja & $99 \%$ \\
Total PDB Nasional & $60,34 \%$ \\
Total Ekspor & $14,17 \%$ \\
Total Investasi & $58,18 \%$ \\
\hline
\end{tabular}

Sumber: Sensus Ekonomi BPS 2016

Tabel 1.1 memperlihatkan kontribusi UMKM terhadap total lapangan kerja mencapai 99\% diikuti oleh kontribusi terhadap tenaga kerja mencapai 97\% (Kemenkop, 2019). Berdasarkan fakta inilah, peneliti mengangkat kelompok usaha UMKM ini sebagai salah satu faktor data panel. Begitu juga dengan faktor jumlah unit UMKM, tenaga kerja, nilai ekspor, dan investasi (permodalan) diperkirakan mempunyai pengaruh terhadap perkembangan UMKM dalam rangka meningkatkan pendapatan nasional (Hamzah L.M, 2019).

Beberapa penelitian mengenai UMKM sudah banyak dilakukan dengan analisis statistika yang berbeda-beda. Penelitian yang dilakukan oleh Saleh, B. dan Hadiya, Y.D menyatakan bahwa persoalan tingkat pendidikan pelaku UMKM sangat berkorelasi dengan kemampuan mereka memanfaatkan TI sebagai sarana pendukung pengelolaan UMKM (Saleh. B, Hadiyat Y.D., 2016). Penelitian tahun 2019 yang dilakukan oleh Elwisam, Lestari.R menyatakan bahwa inovasi produk kreatif, orientasi pasar, dan strategi pemasaran memiliki efek positif pada kinerja pemasaran. Selain itu, pengembangan bisnis juga terbukti berpengaruh pada kinerja pemasaran (Elwisam, Lestari.R., 2019). Tahun 2019, penelitian yang dilakukan oleh Hamza L.M dan Agusten.D. menyatakan bahwa tenaga kerja UMKM dan penempatan UMKM berpengaruh positif dan signifikan terhadap pendapatan nasional sektor UMKM di Indonesia., tetapi jumlah unit UMKM tidak memengaruhi pendapatan nasional sektor UMKM di Indonesia (Hamza L.M, Agustien D., 2019). Keterbaruan penelitian ini selain menggunakan variable bebas yang berbeda, yaitu : jumlah UMKM, tenaga kerja, Ekspor, dan Investasi, analisis yang digunakan adalah analisis Regresi Data Panel dengan data yang digunakan lebih update yakni periode 2014 sd 2018, sektor yang diperhatikan adalah kelompok UMKM yang terdiri dari empat kelompok UMKM yaitu Mikro, Kecil, Menengah, dan Besar.

Analisis regresi data panel merupakan suatu metode yang digunakan untuk memodelkan pengaruh variabel prediktor terhadap variabel respon dalam beberapa sektor yang diamati dari 
suatu objek penelitian selama periode waktu tertentu Regresi data panel merupakan gabungan data Cross Section dan data Time Series, dimana unit Cross Section yang sama diukur pada waktu yang berbeda. Jadi, data panel merupakan data dari beberapa individu yang sama dan diamati dalam kurun waktu tertentu. Jika kita mempunyai $\mathrm{T}$ periode waktu $(\mathrm{t}=1,2,3, \ldots, \mathrm{T})$ dan $\mathrm{N}$ jumlah individu $(\mathrm{n}=1,2,3, \ldots \mathrm{N})$, maka dalam data panel akan diperoleh total data sebanyak N.T buah data. Jika jumlah unit waktu sama untuk setiap individu, maka disebut balanced Panel, jika berbeda disebut unbalanced Panel. Dalam penelitian ini, digunakan analisis regresi data panel untuk menganalisis faktor-faktor yang memengaruhi pertumbuhan UMKM terhadap pendapatan nasional dengan periode tahun 2014 sd 2018, dan jumlah individu adalah 4 kelompok usaha kelompok usaha kecil, mikro, menegah, dan besar. . Selanjutnya, akan dipilih model regresi terbaik yang dapat menggambarkan pengaruh UMKM terhadap pendapatan nasional. Sebagai peubah respon adalah pendapatan nasional. Sedangkan peubah prediktor adalah jumlah tenaga kerja, jumlah unit usaha, investasi, dan ekspor.

\section{METODOLOGI}

Data dalam penelitian ini adalah data sekunder kuantitatif yakni data panel periode 2014 - 2018 dan data silang (cross section) yang melibatkan tiga kelompok usaha UMKM, yaitu: 1). Usaha Mikro 2).Usaha Kecil , 3) Usaha Menengah 4) Usaha Besar yang memiliki kontribusi besar terhadap pendapatan nasional dan kelompok usaha yang variabel independennya sebagai indikator pengembangan UMKM terdapat di setiap variabel. Sumber data berasal dari Kemenkop dan UMKM, BPS, dan BI dari tahun 2014 sampai tahun 2018. Variabel respon adalah pendapatan nasional (PDB) dengan satuan milyar rupiah dan peubah prediktor adalah tenaga krja (TKERJA)dengan satuan orang, jumlah unit usaha (JUSAHA) satuan unit, Investasi UMKM (INVESTASI) dengan satuan juta rupiah, dan Ekspor UMKM (EKSPOR) dengan satuan juta rupiah.

Langkah-langkah penelitian digambarkan dalam diagram alir seperti berikut : 


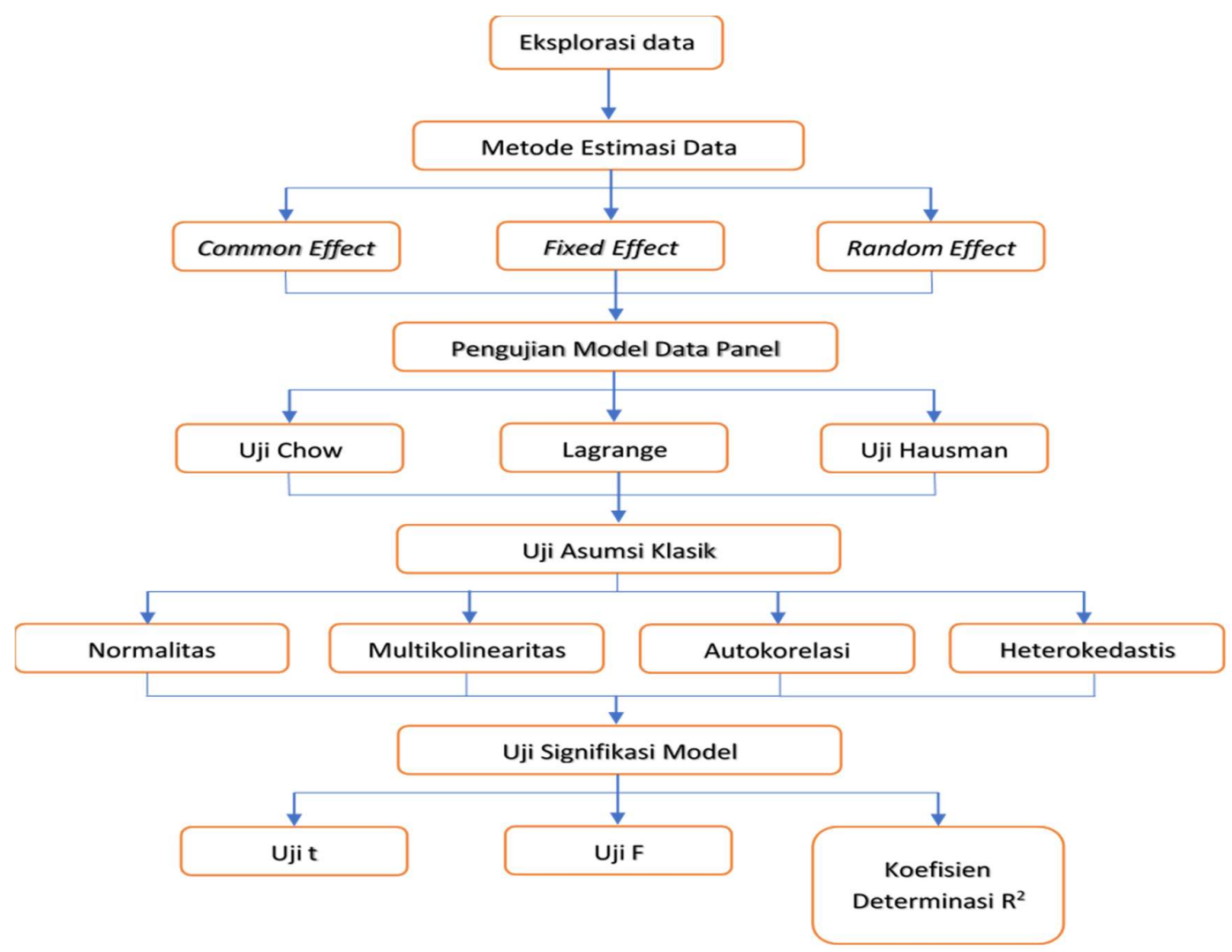

Gambar 2.1 Langkah-langkah Penellitian

Berikut tahapan regresi Data Panel menggunakan software Eviews 10:

Langkah 1 : Penentuan model regresi data panel

a. Uji Chow untuk memilih model terbaik antar CEM dan FEM, jika Ho diterima maka model terpilih adalah CEM, jika ditolak maka model terpilih adalah FEM.

b. Uji Hausmen untuk memilih model terbaik antar FEM dan CEM, jika Ho diterima maka model terpilih adalah REM, jika ditolak maka model terpilih adalah FEM.

c. Uji Lagrange Multiplier untuk memilih model terbaik antara CEM dan REM, jika Ho dierima maka model terpilih adalah CEM, jika ditolak maka model terpilih adalah REM.

d. Menentukan metode estimasi parameter yang tepat dengan melihat struktur varianscovarian dan korelasi antar indivdu dari residualnya menggunakan uji LM (Langrange Multiplier). Apabila model yang terpilih adalah model REM, maka tidak perlu dilakukan pengujian untuk menentukan metode estimasi yang terbaik. 
Langkah 2 : Pengujian asumsi model

a. Uji Normalitas menggunakan Jarque-Bera

b. Uji Multikolinearitas menggunakan nilai VIF

c. Uji Heterokedastisitas menggunakan Heteroskedasticity

d. Uji Autokorelasi menggunakan Durbin Watson

\section{Langkah 3 : Pengujian Estimasi model}

a. Uji parsial (uji t), ), jika Prob(F-statistic) < 0,05, dapat disimpulkan bahwa variabel prediktor secara individu berpengaruh signifikan terhadap var respon

b. Uji serentak (uji F), jika Prob(F-statistic) < 0,05, dapat disimpulkan bahwa variabel bebas secara bersama-sama berpengaruh signifikan terhadap var respon

c. Goodness of fit dari model $\left(\mathrm{R}^{2}\right)$

Deskripsi data variabel respon Pendapatan Nasional (PN), data variabel prediktor :

Jumlah Unit UMKM (JU), Investasi (I), Tenaga Kerja (TK), dan Ekspor (E) berdasrkan tahun dan kelompok usaha.

Pemilihan Model Regresi (Common Effect Model, Fixed Effect Model, Random Effect

Model) yang dinyatakan sebagai : $\mathrm{Y}_{\mathrm{PN}}=\mathrm{f}(\mathrm{JU}, \mathrm{I}, \mathrm{TK}, \mathrm{E})$

Model tersebut jika dituangkan dalam bentuk persamaan sebagai berikut :

$$
\mathrm{Y}_{\mathrm{it}}=\beta \mathrm{o}+\beta_{1} \mathrm{JU}_{\mathrm{it}}+\beta_{2} \mathrm{I}_{\mathrm{it}}+\beta_{3} \mathrm{TK}_{\mathrm{it}}+\beta_{4} \mathrm{E}_{\mathrm{it}}+e_{i t}
$$

Keterangan : $\quad \mathrm{Y}_{\mathrm{it}}=$ Pendapatan Nasional kelompok usaha $\mathrm{i}$, tahun $\mathrm{t}$

$$
\begin{aligned}
& \mathrm{i}=1,2,3, \ldots . \mathrm{n}(\text { kelompok usaha }) \\
& \mathrm{t}=1,2,3, \ldots . \text { ( Banyaknya periode waktu) } \\
& \beta_{\mathrm{o}}=\text { Intercep. } \\
& \beta_{1}=\text { Slope } / \text { koefisien Jumlah Unit }(\mathrm{JU}) \\
& \beta_{2}=\text { Slope } / \text { koefisien Investasi (I) } \\
& \beta_{3}=\text { Slope } / / \text { koefisien Tenaga Kerja (TK) } \\
& \beta_{4}=\text { Slope / koefisien Ekspor }(\mathrm{E})
\end{aligned}
$$

\section{PEMBAHASAN}

Berikut adalah deskripsi data penelitian dari peubah - peubah yang digunakan perioede tahun 2014 sd 2018 berdasarkan kelompok usaha: 


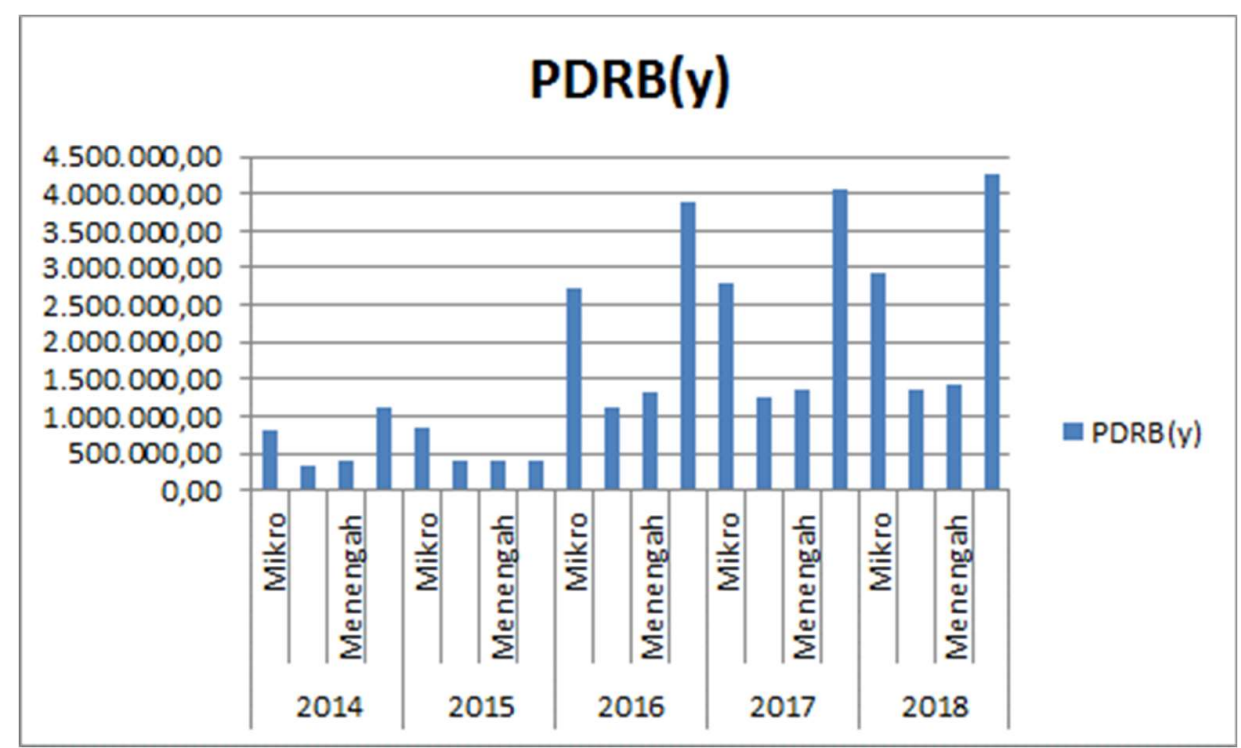

Gambar 3.1 PDB Kelompok UMKM Berdasarkan

Kelompok Usaha Tahun 2014 sd 2018

Gambat 3.1 memperlihatkan bahwa nilai PDB (Pendapatan Nasional) minimal terjadi pada tahun 2014 dari semua kelompok usaha. Selama lima tahun, kelompok UMKM skala besar memberikan kontribusi nilai PDRB menjadi naik.

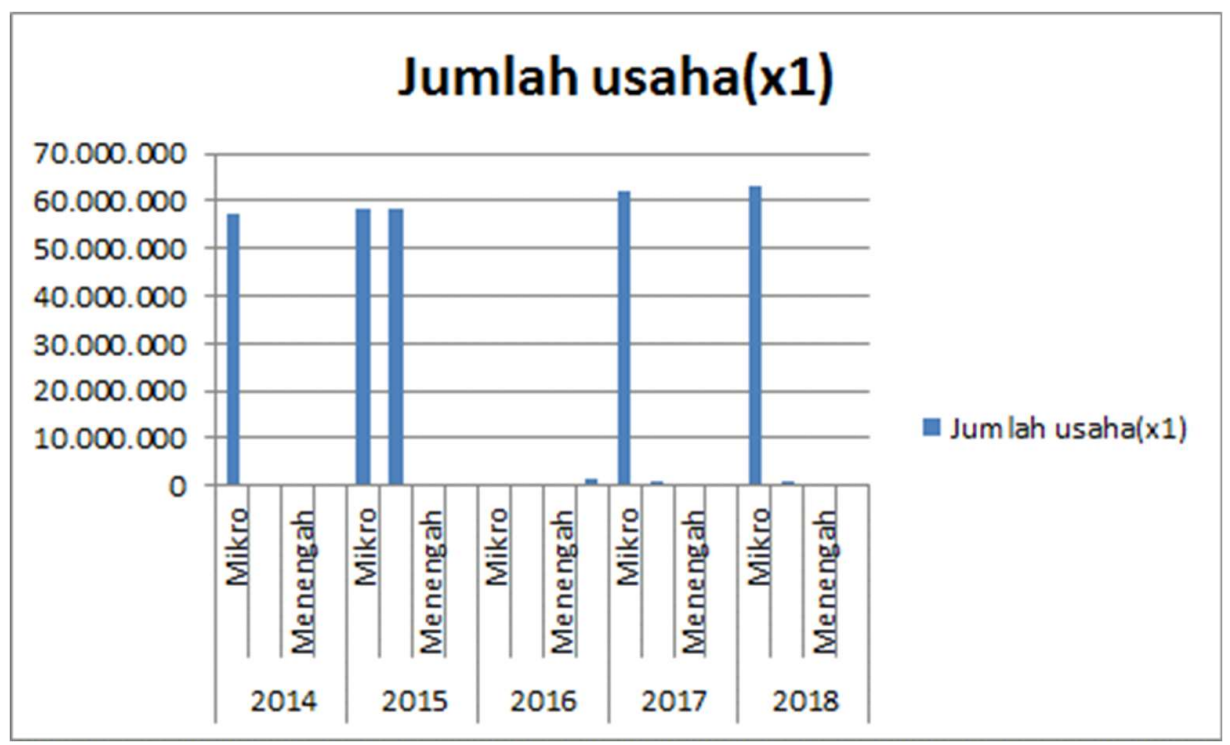

Gambar 3.2 Jumlah Unit Usaha Kelompok UMKM Berdasarkan

Kelompok Usaha Tahun 2014 sd 2018

Berdasarkan gambar 3.2, dapat ditunjukkan bahwa banyaknya unit jumlah usaha kelompok mikro berekembang pesat selama tahun 2014 sd 2018 


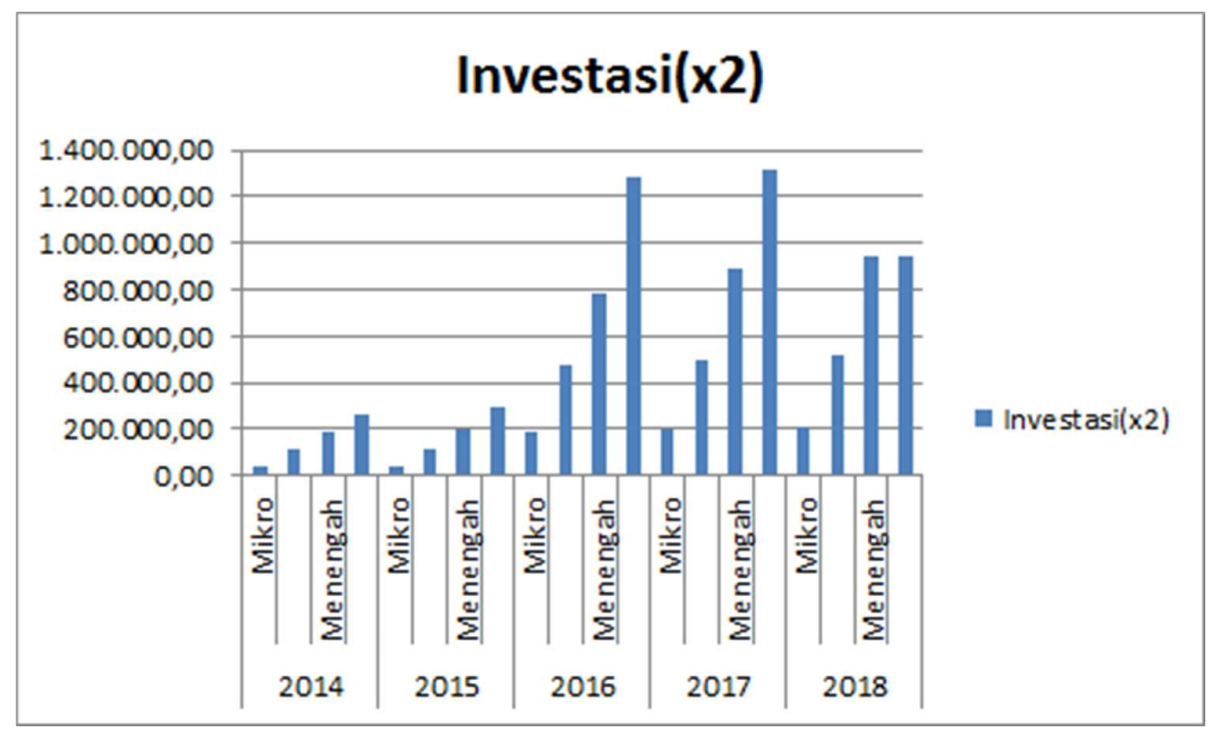

Gambar 3.3 Nilai Investasi Kelompok UMKM Berdasarkan

Kelompok Usaha Tahun 2014 sd 2018

Berdasarkan gambar 3.3, dapat diperlihatkan bahwa nilai investasi berkembang pesat untuk kelompok UMKM skala besar sejak tahun 2016 disusul oleh kelompok UMKM skala menengah.

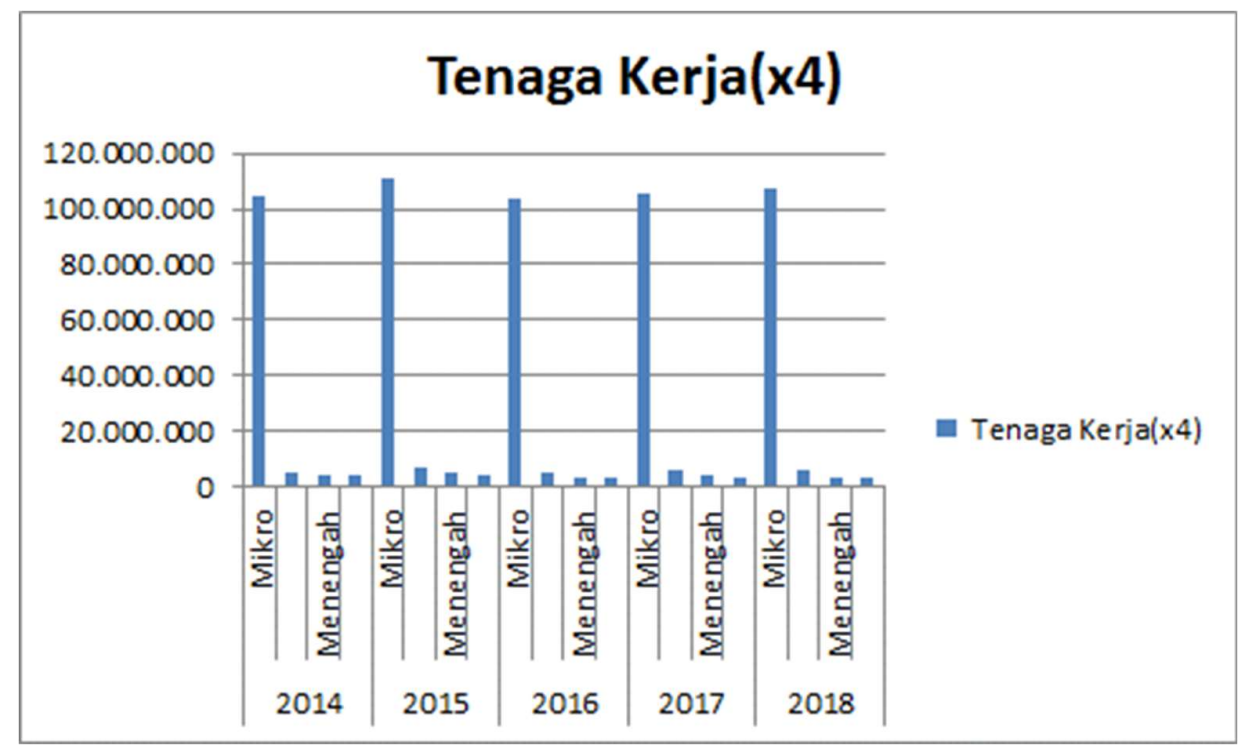

Gambar 3.4 Banyaknya Tenaga Kerja Kelompok UMKM Berdasarkan

Kelompok Usaha Tahun 2014 sd 2018

Gambar 3.4 memperlihatkan bahwa Jumlah tenaga kerja kelompok UMKM skala Mikro relatif stabil selama tahun 2014 sd 2018 


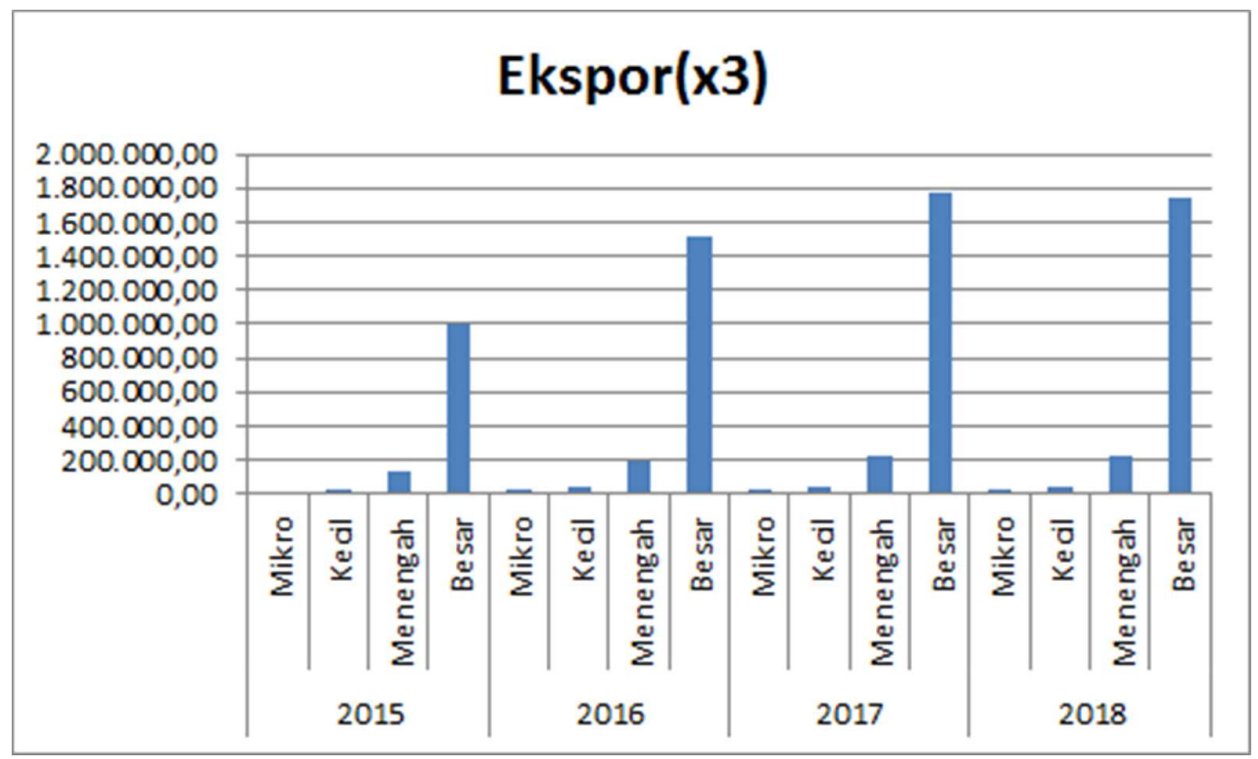

Gambar 3.5 Nilai Ekspor Kelompok UMKM Berdasarkan

Kelompok Usaha Tahun 2014 sd 2018

Berdasarkan gambar 3.5, dapat ditunjukkan bahwa Ekspor kelompok UMKM skala besar relatif stabil dan tinggi selama lima tahun.

Tabel 3.1 Statistika Deskriptif Data Penelitian

\begin{tabular}{lccccc}
\hline \multicolumn{1}{c}{ Statistik } & PDRB & JUSAHA & INVESTASI & EKSPOR & TKERJA \\
\hline Mean & 1664098. & 15197918 & 476093.1 & 411845.7 & 30132429 \\
Median & 1292010. & 123786.2 & 278617.3 & 91890.20 & 5258047. \\
Maximum & 4274158. & 63350222 & 1317929. & 1772195. & $1.11 \mathrm{E}+08$ \\
Minimum & 342579.2 & 4987.000 & 42053.30 & 15562.00 & 3444746. \\
Std. Dev. & 1299653. & 26532238 & 408810.7 & 618053.6 & 45225289 \\
Skewness & 0.861662 & 1.161278 & 0.831232 & 1.381170 & 1.155716 \\
Kurtosis & 2.391688 & 2.361014 & 2.386266 & 3.261864 & 2.342765 \\
Jarque-Bera & 2.783243 & 4.835475 & 2.617044 & 6.415912 & 4.812227 \\
Probability & 0.248672 & 0.089123 & 0.270219 & 0.040439 & 0.090165 \\
Sum & 33281958 & $3.04 \mathrm{E}+08$ & 9521862. & 8236913. & $6.03 \mathrm{E}+08$ \\
Sum Sq. Dev. & $3.21 \mathrm{E}+13$ & $1.34 \mathrm{E}+16$ & $3.18 \mathrm{E}+12$ & $7.26 \mathrm{E}+12$ & $3.89 \mathrm{E}+16$ \\
\hline Observations & 20 & 20 & 20 & 20 & 20 \\
\hline
\end{tabular}

Tabel 3.1 menunjukkan bahwa rata-rata PDRB tahun 2014 sd 2018 mencapai Rp 1664098 milyar dengan nilai minimum Rp 342579,2 milyar dan maksimumsebesar Rp 4274158 milyar. Rata-rata jumlah usaha mencapai 15197918 unit dengan nilai minimum adalah 4987000 unit dan maksimum sebesar 63350222 unit. Investasi mencapai nilai maksimum sebesar Rp 1317929. milyar dan nilai minimum adalah Rp 42053,30 milyar dengan nilai 
rata-rata sebesar Rp 476093,1 milyar. Ekspor dari berbagai keompok UMKM mempunyai rata-rata Rp 411845,7 milyar dengan minimum sebesar Rp 15562 milyar dan maksimum sebesar Rp 1772195 milyar. Jumlah tenaga kerja yang terserap pada berbagai kelompok UMKM mempunyai rata -rata 30132429orang dan jumlah minimum yang terserap 3444746 orang dan mencapai maksimum pada 111000000 orang.

\subsection{Hasil Analisis Penelitian}

Tabel 3.2 Hasil Output Model Common Effect

\begin{tabular}{crrrr}
\hline \hline \multicolumn{1}{c}{ Variable } & Coefficient & Std. Error & t-Statistic & Prob. \\
\hline \hline C & -272935.6 & 319189.1 & -0.855091 & 0.4060 \\
X1 & -0.002305 & 0.008645 & -0.266599 & 0.7934 \\
X2 & 2.090328 & 0.537652 & 3.887880 & 0.0015 \\
X3 & 0.927729 & 0.327774 & 2.830395 & 0.0127 \\
X4 & 0.019739 & 0.005069 & 3.893895 & 0.0014 \\
\hline \hline R-squared & 0.806409 & Mean dependent var & 1664098. \\
Adjusted R-squared & 0.754784 & S.D. dependent var & 1299653. \\
S.E. of regression & 643578.2 & Akaike info criterion & 29.79979 \\
Sum squared resid & $6.21 \mathrm{E}+12$ & Schwarz criterion & 30.04873 \\
Log likelihood & -292.9979 & Hannan-Quinn criter. & 29.84839 \\
F-statistic & 15.62071 & Durbin-Watson stat & 0.992655 \\
Prob(F-statistic) & 0.000032 & & \\
\hline \hline
\end{tabular}

Tabel 3.3 Model Fixed Effec

\begin{tabular}{crrrr}
\hline \hline Variable & Coefficient & Std. Error & t-Statistic & Prob. \\
\hline \hline JUSAHA & -0.002208 & 0.008981 & -0.245887 & 0.8099 \\
INVESTASI & 1.488594 & 0.662060 & 2.248429 & 0.0441 \\
EKSPOR & 2.673429 & 1.119559 & 2.387931 & 0.0343 \\
TKERJA & -0.107725 & 0.113351 & -0.950367 & 0.3607 \\
C & 3133921. & 3391481. & 0.924057 & 0.3737 \\
\hline \hline
\end{tabular}

Effects Specification

Cross-section fixed (dummy variables)

\begin{tabular}{lrll}
\hline \hline R-squared & 0.875838 & Mean dependent var & 1664098. \\
Adjusted R-squared & 0.803411 & S.D. dependent var & 1299653. \\
S.E. of regression & 576244.8 & Akaike info criterion & 29.65563 \\
Sum squared resid & $3.98 \mathrm{E}+12$ & Schwarz criterion & 30.05392 \\
Log likelihood & -288.5563 & Hannan-Quinn criter. & 29.73338 \\
F-statistic & 12.09261 & Durbin-Watson stat & 1.004468 \\
Prob(F-statistic) & 0.000138 & &
\end{tabular}

Hipotesis Uji Chow Ho : Model Common Effect H1 : Model Fixed Effect 
Redundant Fixed Effects Tests

Tabel 3.4 Uji Chow

Equation: Untitled

Test cross-section fixed effects

\begin{tabular}{lrrr}
\hline \hline Effects Test & Statistic & d.f. & Prob. \\
\hline \hline Cross-section F & 2.236754 & $(3,12)$ & 0.1365 \\
Cross-section Chi-square & 8.883311 & 3 & 0.0309
\end{tabular}

Berdasarkan uji Chow, dapat ditunjukkan bahwa nilai Probabilitas Cross-section Chi Square $=0,0309$ kurang dari 0,05 sehingga Ho ditolak, artinya model terbaik adalah Model Fixed Effect. Uji Random acak tidak dilakukan, karena jumlah variabel sama dengan banyaknya pengelonpokan (jumlah silang bagian) yakni empat. Sedangkan menurut aturan Eviews, Estimasi Random acak membutuhkan jumlah silang bagian lebih besar dari jumlah koefisien untuk antara penduga untuk perkiraan varians.

\subsection{Uji asumsi untuk model Fixed Effect adalah sebagai berikut :}

\section{a. Uji Normalitas}

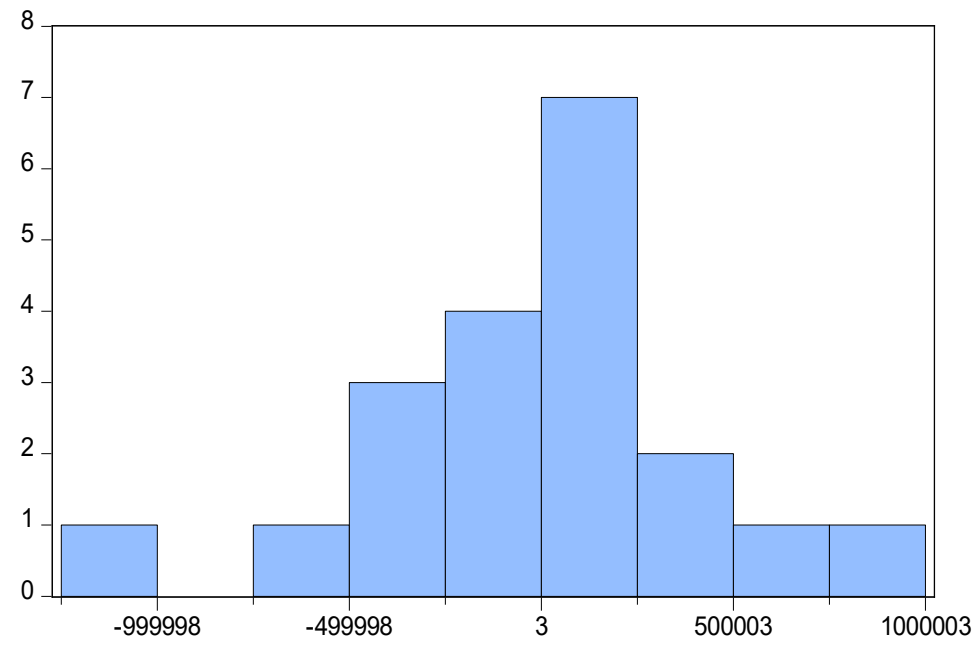

Gambar 3.6 Uji Normalitas
Series: Standardized Residuals Sample 20142018

Observations 20

Mean $\quad-3.06 \mathrm{e}-10$

Median $\quad 90084.49$

Maximum $\quad 924668.1$

Minimum $\quad-1236986$.

Std. Dev. $\quad 457952.9$

Skewness $\quad-0.599320$

Kurtosis $\quad 4.285397$

Jarque-Bera 2.574154

Probability $\quad 0.276077$

Gambar 3.6 memperlihatkan bahwa nilai Probabilitas residual adalah 0,333644 lebih besar dari 0,05 maka Ho diterima. Artinya residual berdistribusi normal.

b. Uji Multikolinearitas

Tabel 3.5 Korelasi antar Variabel Independen

\begin{tabular}{crrrr}
\hline & JUSAHA & INVESTASI & EKSPOR & \multicolumn{1}{c}{ TKERJA } \\
\hline JUSAHA & 1.000000 & -0.505835 & -0.371603 & 0.750698 \\
INVESTASI & -0.505835 & 1.000000 & 0.682803 & -0.502900 \\
EKSPOR & -0.371603 & 0.682803 & 1.000000 & -0.387205 \\
TKERJA & 0.750698 & -0.502900 & -0.387205 & 1.000000 \\
\hline
\end{tabular}


Berdasarkan tabel 3.5, dapat ditunjukkan bahwa nilai absolut dari korelasi antar variabel Peubah prediktor kurang dari 0,8 , artinya tidak terjadi multikolinearitas antara peubah prediktor.

\section{c. Uji Heterokedastisitas}

Tabel 3.6 Uji Heterokedastisitas dengan Eviews

\begin{tabular}{lrc}
\hline \hline \multicolumn{1}{c}{ Test } & Statistic & Prob. \\
\hline \hline Breusch-Pagan LM & 9.364831 & 0.1541 \\
Pesaran scaled LM & 0.971343 & 0.3314 \\
Bias-corrected scaled LM & 0.471343 & 0.6374 \\
Pesaran CD & -1.302955 & 0.1926 \\
\hline \hline
\end{tabular}

Berdasarkan tabel 6, dapat ditunjukkan bahwa nilai probabilitas untuk BreuschPagan LM adalah 0,1541 lebih besar dari 0,05 maka Ho diterima, artinya tidak terjadi heterokedastisitas.

\section{d. Uji Autokorelasi}

Tabel 2 memperlihatkan model Fixed Effect dengan nilai Durbin Watson $\mathrm{dw}=1.004468$ Menurut tabel Durbin Watson, untuk $\mathrm{k}=4$, dengan nilai $\mathrm{n}=20$ maka nilai $\mathrm{dl}=0,8943$ dan $\mathrm{du}=1,8283$. Karena nilai $\mathrm{dw}=1.004468$ tidak terletak diantara du dan (4$\mathrm{du})=(4-1.004468)=2,995532$, tetapi terletak diantara $\mathrm{dl}$ dan $\mathrm{du}$, jadi tidak dapat disimpulkan. Sehingga digunakan cara untuk mengatasi masalah kondisi ini, yakni dengan Cochrane Orcutt, diperoleh hasil sebagai berikut :

Tabel 3.7 Uji Autokorelasi dengan Cochrane Orcutt

\begin{tabular}{lrll} 
R-squared & 0.870054 & Mean dependent var & 1913228. \\
Adjusted R-squared & 0.805081 & S.D. dependent var & 1334325. \\
S.E. of regression & 589099.1 & Akaike info criterion & 29.69057 \\
Sum squared resid & $3.47 \mathrm{E}+12$ & Schwarz criterion & 29.98029 \\
Log likelihood & -231.5246 & Hannan-Quinn criter. & 29.70541 \\
F-statistic & 13.39102 & Durbin-Watson stat & 2.361681 \\
Prob(F-statistic) & 0.000366 & & \\
\hline \hline
\end{tabular}

Berdasarkan tabel 3.7, nilai Durbin Watson $=2.361681$ terletak diantara du dan (4du), sehingga dapat disimpulkan bahwa tidak terjadi autokorelasi.

Dengan demikian, semua asumsi sudah dipenuhi, sehingga layak dilanjutkan langkah berikutnya. 


\subsection{Model Fixed Effect yang terbentuk adalah :}

$\mathrm{PDB}=3133921-0,002208$ JUSAHA +1,488594 INVESTASI +2,673429 EKSPOR 0,107725 TKERJA

Interpretasi : Setiap JUSAHA dan TKERJA bertambah 1 unit maka akan menyebabkan turunnya nilai PDB dan sebaliknya setiap pertambahan variabel INVESTASI, EKSPOR, dan TKERJA sebesar satu satuan akan menyebabkan nilai PDB juga naik. Nilai Ajusted R-Squared adalah 0.803411 artinya 80,34\% kontribusi dari variabel-variabel JUSAHA,INVESTASI,EKSPOR,TKERJA terhadap variabel PDB, sisanya 19,66\% dipengaruhi faktor lain yang tidak dibahas dalam penelitian ini. Berdasarkan output Eviews dapat ditunjukkan bahwa variabel-variabel bebas yang memengaruhi PDB (Pendapatan Nasional) adalah INVESTASI dengan probabilitas 0,0441 kurang dari 0,05 artinya cukup signifikan. Variabel bebas lainnya adalah EKSPOR dengan nilai probabilitas adalah 0,0343, juga lebih kecil dari 0,05 artinya cukup signifikan. Dan secara simultan, keempat variabel bebas tersebut memberi pengaruh signifikan terhadap PDB. Hal ini dapat ditunjukkan oleh nilai probabilitas (F-statistic) sebesar 0,000138 kurang dari 0,05

\section{SIMPULAN}

Berdasarkan uraian dan analisis pembahasan di atas dapat disimpulkan bahwa : Model terbaik dalam penelitian ini adalah Model Fixed Effect dan variabel bebas yang memengaruhi PDB (pendapatan nasional) secara signifikan adalah INVESTASI dan EKSPOR. Kontribusi variabel -variabel bebas terhadap PDB (pendapatan nasional ) adalah $80,34 \%$, artinya $80,34 \%$, PDB (pendapatan nasional) dipengaruhi oleh JUSAHA, INVESTASI, EKSPOR, TKERJA, sisanya 19,66 \% dipengaruhi faktor lain yang tidak dibahas dalam penelitian ini. Berdasarkan model Fixed Effect yang diperoleh, dapat ditunjukkan bahwa kenaikan JUSAHA dan TKERJA akan menurunkan nPDRB (Pendapatan Nasional); Sedangkan kenaikan Jumlah INVESTASI dan EKSPOR akan menaikkan nilai pendapatan nasional. Kelompok usaha UMKM yang memberikan kontribusi paling tinggi pada pendapatan nasional berdasarkan variabel cukup berbeda. Kelompok UMKM yang memberikan nilai INVESTASI dan EKSPOR maksimum pada pendapatan nasional adalah kelompok UMKM Besar periode tahun 2014 sd 2018. 
Kelompok UMKM Mikro memberikan kontribusi maksimum pada pendapatan nasional berdasarkan faktor JUSAHA dan TKERJA selama periode 2014 sd 2018.

\section{DAFTAR PUSTAKA}

Elwisam, Lestari.R. (2019). Penerapan Strategi Pemasaran, Inovasi Produk Kreatif dan Orientasi Pasar untuk Meningkatkan Kinerja Pemasaran UMKM. Jurnal Riset Manajemen dan Bisnis (JRMB) Fakultas Ekonomi Universitas Nasional Jakarta.

H. A. (2019). Pengaruh Perkembangan Usaha Mikro, Kecil, Dan Menengah Terhadap Pendapatan Nasional Pada Sektor UMKM Di Indonesia. Ekonomi Pembangunan, 8 .

Hamza L.M, Agustien D. (2019). Pengaruh Perkenbangan Usaha Mikro, Kecil, dan Menengah terhadap Pendapatan Nasional pada Sektor UMKM. Jurnal Ekonomi Pembangunan.

Kemenkeu. (2018). Ini Bentuk Perhatian Pemerintah terhadap UMKM.

Kemenkeu. (2018). Ini Bentuk Perhatian Pemerintah terhadap UMKM.

Kemenkop, d. U. (2019). Sinergitas Pengembangan KUMKM melalui Penguatan Peran antar Lembaga.

Kemkominfo. (2018).

Rahmini, Y. (2017). Perkembangan UMKM di Indonesia. Cano Ekon, 61 jan .

Saleh. B, Hadiyat Y.D. (2016). Penggunaan Teknologi Informasi di Kalangan Pelaku Usaha Mikro Kecil Menengah di Daerah Perbatasan (Studi Kasus di Kab. Belu Prov. NTT). Pekommas. 